\title{
Configuring Human Rights at EuroPride 2015
}

\section{Introduction}

Events, predominantly sport mega-events, have received an abundance of academic scrutiny. Some of these commentaries have critiqued how the staging of mega-events can violate a range of universal human rights. Far less is available that is concerned with how events are mobilised for human rights advocacy. Moreover, the critical study of events as 'politics, activism and leisure' (Lamond \& Spacklen, 2014, p. 1) is a relatively new field of inquiry.

In recent times, global Pride events have adopted explicit statements of human rights claiming. In Central and Eastern Europe (CEE) they have been viewed as 'central events' to the struggle for sexual rights (Kalina, 2014, p. 5), and to processes of democratisation (Holzhacker, 2013). These points are evidenced in this pre-EuroPride 2015 public statement:

EuroPride is one of Europe's main LGBT events. This EuroPride marks a historic occasion as the first EuroPride to be held in a post-Soviet country on the EU's Eastern border with Russia. This year's event provides an invaluable opportunity to draw pan-European attention to LGBT and human rights in the region. http://www.europride2015.eu/press-europride-2015-will-take-place-in-rigalatvia/

This paper, drawing from an on-going qualitative research project (Baltic Pride 20152017), focuses on the venacularization of human rights to offer a view of the intricacies of LGBT (lesbian, gay, bisexual and transgender) activism at the level of the local. Discussion starts with an appraisal of existing universal human rights policies surrounding sexual orientation and gender identity (SOGI), specifically United Nations (UN) and European Union (EU) legislative frameworks. This legislative premise is followed by a focus on vernacularization; a concept that reveals the complicated processes of human rights claiming. A brief history of Baltic Pride provides the context for EuroPride 2015 as well as the subsequent analyses of research findings, which are explored through the themes: EuroPride 2015 Pride House and EUroPride's Super VIPs. Methodologically, the research relies on a combination of ethnography and autoethnogarphy, and findings are embedded within the critical analyses. Photographs, 
field notes that are more akin to autoethnographic narrative, and commentary from the interview participants highlight the conceptual value of vernacularization to research on human rights.

\section{Sexual orientation and gender identity (SOGI), and human rights}

"Where, after all, do universal human rights begin? In small places, close to home - so close and so small that they cannot be seen on any maps of the world.... Such are the places where every man, woman and child seeks equal justice, equal opportunity, equal dignity without discrimination".

Eleanor Roosevelt (1958 speech delivered on the 10th anniversary of the Universal Declaration of Human Rights)

"As men and women of conscience, we reject discrimination in general, and in particular discrimination based on sexual orientation and gender identity.... Where there is a tension between cultural attitudes and universal human rights, rights must carry the day. ... Violence will end only when we confront prejudice. Stigma and discrimination will end only when we agree to speak out. That requires all of us to do our part. To speak out - at home, at work, in our schools and communities".

Ban Ki-moon (2010 speech delivered on Human Rights Day)

The Universal Declaration of Human Rights (UDHR)(1948) does not include explicit reference to sexual orientation and gender identity (SOGI). However, embedded in Article 2: Everyone is entitled to all the rights and freedoms set forth in this Declaration, without distinction of any kind, such as race, colour, sex, language, religion, political or other opinion, national or social origin, property, birth or other status, there appears to be scope for LGBT rights within the final catch-all phrase. In a comparative study of the UN and EU qua LGBT human rights, Sweibal (2009) is critical of this lack of engagement by the UN. Moreover, Takhar (2015) highlights that at international level sexual rights have focused predominantly on women's sexuality and reproduction rights. With that said, The General Assembly of the UN recently made recommendations related to human rights and SOGI (e.g. A/HRC/RES/17/19 (2011) and A/HRC/27/L.27/Rev.1 (2014)). ${ }^{i}$ And yet, the conclusion made by the UN General Assembly on 24th September 2014 confirms that it: 'Decides to remain seized of this issue'.

In 2011, there was a Recalling further by the General Assembly (A/HRC/RES/17/19) to the resolution 60/251 of $15^{\text {th }}$ March 2006 and the responsibility of the Human Rights 
Council for promoting universal respect, and the protection against violent and discriminatory acts. In resolution 17/19, Expression of grave concern was registered for acts of violence and discrimination committed against people on the basis of SOGI. A vote of 23 to 19 ( 3 abstentions) supported the Request to the UN High Commissioner for Human Rights-in the form of a directive-to study and document discriminatory laws, practices and acts of violence against people because of their SOGI. This appeal applied to all regions of the world, and included the request for prevention through international human rights law.

The first report by the Office of the High Commission for Human Rights (OHCHR) to concern LGBT people appeared on 17th November 2011 (A/HRC/19/4). The 25-page document ${ }^{\mathrm{ii}}$ details violence, discriminatory laws and discriminatory practices, including: murder, rape, torture, criminalisation, arrest, detention, restrictions of freedom of expression, association, assembly, and the denial of recognition of same-sex relationships, and gender recognition. Citing specific cases and identifying a number of countries, the report calls for the universality of equality and non-discrimination as well as individual state's obligation under international law. In the document, various Articles from UDHR are listed (i.e., 1,2,3,5,6,9,12,17,19,20,26,33) as providing the legislative framework for the protection and promotion of LGBT human rights.

Following this publication, the UN published a booklet (2012) through the Office of the High Commissioner entitled: Born Free and Equal: Sexual Orientation and Gender Identity in International Human Rights Law. It documents further the core legal obligations of states.

In 2014, the adoption of resolution A/HRC/27/L.27/Rev.1 by a vote of 25 to 14 (7 abstentions) by the General Assembly is significant in moving forward human rights apposite to SOGI. However, the continued citation of UDHR and existing resolutions $60 / 251$ and 17/19, as well as the Vienna Declaration and Program of Action (25 th June 1993) and the request to update the 2011 study and report, provide evidence of the indolence of implementation in some countries.

Regional bodies have also addressed human rights and SOGI. The EU is viewed as 
relatively successful as a consequence of a number of factors including the accomplishments of the European branch of the International Lesbian and Gay Association (ILGA), iii and their work to gain access, define terms and set agendas at the level of policy formation (Swiebel, 2009). In 1997, the adoption of Article 13 of the European Community (EC) Treaty (TEC) marked the first reference to sexual orientation, which was listed as one form of discrimination. In this way, human rights based on sexual orientation entered official EU legislative discourse. These rights were further defined through the Charter of Fundamental Rights of the European Union (2000) and Article 21 iv (Kahlina, 2014).

What is noticeable, and disappointing, is that gender identity was not inscribed in EU human rights instruments until much later. Additionally, both sexuality and gender remain absent in terms of intersex peoples' rights although documentation has emerged recently (FRA, 2015). Transgender and transphobia appeared for the first time when the Council of European adopted Recommendation CM/Rec(2010)5 in March 2010. ${ }^{v}$ In recognising that lesbian, gay, bisexual and transgender persons have been for centuries and are still subjected to homophobia, transphobia and other forms of intolerance and discrimination, $\mathrm{CM} / \operatorname{Rec}(2010) 5$ makes key recommendations to Member States, including:

1. examine existing legislative and other measures, keep them under review, and collect and analyse relevant data, in order to monitor and redress any direct or indirect discrimination on grounds of sexual orientation or gender identity;

2. ensure that legislative and other measures are adopted and effectively implemented to combat discrimination on grounds of sexual orientation or gender identity, to ensure respect for the human rights of lesbian, gay, bisexual and transgender persons and to promote tolerance towards them;

3. ensure that victims of discrimination are aware of and have access to effective legal remedies before a national authority, and that measures to combat discrimination include, where appropriate, sanctions for infringements and the provision of adequate reparation for victims of discrimination.

Clearly, a rack of human rights instruments exist—endorsed by the UN and EU-that makes unlawful acts of violence and discriminatory practices related to SOGI. In this paper, I seek to determine the connections between these legislative universal human rights instruments and the particular "... small places, close to home" (Roosevelt, 1958) such as "... at home, at work, in our schools and communities" (Ki-moon, 2010). 


\section{Human rights claiming and vernacularization}

A return to the statement made by Ki-moon (2010): "Where there is a tension between cultural attitudes and universal human rights, rights must carry the day", provides important opportunity to visit debates surrounding universalism and cultural relativism, and to examine the flows and confluences of global and local human rights discourses and practices. Boyce (2014) documents the tensions between universal human rights specific to SOGI and local cultures in his studies of male sexualities in West Bengal, India when he tracks: '... the globalisation of political discourses and practices concerning sexual rights versus local meanings ... in terms that complicate each variable, such that neither the transnational nor the local appear as simplistically intelligible or contrastive' (1204-05). Vernacularization offers one conceptual approach to explore the disjuncture between the universal and culturally relative that is obscured by Kim-moon's simple dictate that "[universal]rights must carry the day" (2010).

Merry $(1997,2006)$ who is known for her work in human rights and violence against women, is frequently attributed with coining the concept of vernacularization. For her, vernacularization describes the processes involved when human rights packages travel from global sites of production (e.g. UN in Geneva and New York) to local sites of activism. This movement from predominantly western/global north, modern, capitalist, neo-liberal contexts to different and diverse local cultures, is often rapid given contemporary processes of globalisation. And yet, according to Merry more friction than flow is common during this migration. This is because vernacularization entails adaption, appropriation, customisation, evolution, legitimisation as well as disregard and neglect. Working with Levitt (2009), Merry has shaped and re-shaped aspects of the concept to include notions of replication, hybridity, framing, indigenization, resonance and advocacy. She argues that local agents and activists ${ }^{\text {vi }}$ use various practices to put human rights into the vernacular: 'human rights ideas are repackaged in culturally resonant wrappings' (2006: 221). In this way, universal human rights are reinterpreted, transformed, re-formed, culturally inflected, and emergent.

Cheng (2011) in her work on 'the paradox of vernacularization', highlights a shortfall when she claims that: '[Merry] side-stepped one important discussion: for whose good and to what extent do women's human rights get vernacularized?' (478-9). Cheng's turn 
to how state nation-building and national values refract international human rights laws demonstrates the political nature of vernacularization, which operates above local sites and local activists. In her study, 'national values' related to women's sexuality are mobilised through human rights frameworks to deny women sex workers' rights. For Cheng:

... vernacularization of women's human rights and the anti-trafficking initiatives is part of this "double movement" - a necessary gesture to gain and retain membership in a new world order of global modernities, and a key site to assert defense of nationalist culture and tradition. (498)

Similarly, Murray (2006) raises questions concerning the neatness of the concept (vernacularization) when he explores the nuances of 'sexual rights and social change in Barbados'. He demonstrates how different meanings are attached to not only human rights - which he highlights are often viewed as imperialistic-but also to sexuality, especially in countries/societies that develop notions of morality founded upon theology and religiosity. As Takhar (2015) points out in her analysis of the local-global nexus of sexuality and human rights, the notion of a 'global gay citizen' is problematic. Concurring with Murray (2006), Takhar (2015) demonstrates how 'universal definitions of sexuality [are] often regarded as western, corrupting and colonising' (30). And yet, as Murray (2006) demonstrates through his story of Pat who is a member of a gay support group who carries with him the UDHR (two sheets of paper he has downloaded from the www, which he presents when he feels he deserves to be treated with dignity and respect), formal universal human rights do exist in Barbados. Murray's anecdote illustrates the 'Ghostly'vii nature of UDHR. It also demonstrates the local 'vernacular strategies' embedded in the daily lives of sexual and gender minorities. His point contributes to the idea that individual agented responses are significant when we discuss the vernacularization of human rights.

Clearly, there are everyday incidents when sexual and gender minorities face abuse, brutality, discrimination, exclusion, fatality, marginalization and severe hostility. There are also significant moments when LGBT individuals report positive affectual connections within family, friendship groups and wider communities (Boyce, 2014; Murray, 2006). During these affectual, glocalised and particular lived occasions, universal human rights and global activist movements such as Pride can become 
meaningless. Therefore, it is important to note that vernacularization is not always presence and/or intelligible.

\section{EuroPride and Baltic Pride}

There are many Pride parades that take place in towns and cities around the world. The histories and scale of these events vary enormously. Some adopt en-masse celebration and carnivalesque styles while others face the most severe opposition (e.g. Uganda Pride in Entebbe, 2012-2016). Global manifestations of Pride are uneven, and yet, they are connected. Most tend to take place in and around the month of June because of the legacies of USA-based LGBT liberation triggered by the Stonewall Riots (June 29th 1969 in Greenwich Village). In many instances, Pride has come to represent LGBT response to practices and cultures that operate to intentionally, and unintentionally, shame gender and sexual minorities. In this way, Pride functions as a rallying call for equality and just treatment. ${ }^{\text {viii }}$ Through visibility, celebration and protest, the concept of Pride has developed generative and productive symbolic value, including LGBT human rights claiming.

EuroPride, which was first held in London in 1992 attracting a crowd of 100,000, is awarded annually to European countries. In 2012, against a backdrop of national religious and political opposition, ${ }^{\text {ix }}$ Rīga was granted EuroPride 2015. This followed Rīga's other pan-European successes, including Cultural Capital of Europe in 2014, Latvia's entry into the euro-zone (2014) and concomitant presidency of Council of Europe in 2015.

The on-the-ground organisation that took charge of the delivery of the EuroPride event was Mozaīka: LGBT and their friends alliance. Mozaīka has a virtual presence (cf. http://mozaika.lv and https://www.facebook.com/mozaikalv) and a physical office space in Rìga. It is predominantly a voluntary organisation. In the run up to EuroPride, Mozailka raised funds to secure the EuroPride license payable to the European Pride Organisers Association, and members of Mozailka liaised with state and city police authorities concerning the policing of the EuroPride. ${ }^{x}$ During the weeklong Pride event, Mozaīka, its members and volunteers planned and delivered a schedule of activities, including film screenings, conferences and workshops. 
The first Pride parade to be held in Riga was in 2005, the year after Latvia joined the European Union. This small public gathering (70 participants) faced thousands of onlookers, and severe verbal and physical hostility from those protesting against homosexuality. In 2006, Rīga City Council banned Pride citing a "threat of violence" (cited in Dzenovska \& Arenas, 2012: 649). As a consequence, Rīga Pride took place mostly behind the closed doors of the Reval Hotel and the Anglican Church (see: Homo@lv). Despite the covertness of the event, aggressive public opposition meant that 14 protestors were arrested. Key individuals living outside of Latvia, including an endorsement by Ken Livingstone in his speech at London Pride (2007), helped support Rīga Pride 2007, which took placed in the enclosed Vērmanes Dārzs Park. The event attracted 800 participants who gathered under the banner of Rīga Friendship Days and Equality Parade. This language of friendship and equality reflects a move to de-fuse homophobic response by deflecting opposition from the seemingly loaded term: Pride. This appropriation of slogans of inclusion was common during this era and Woodcock (2011) and Blagojević (2011) document similar strategic responses to public aggressions at Pride in Romania and Serbia respectively.

One more Rīga Pride occurred in 2008. Despite a heavy police presence, participants (600) continued to encounter homophobic opposition and 'the virulence of antigay rhetoric in the public sphere' (O'Dwyer \& Schwartz, 2010: 222). After 4 years of efforts to hold Pride in Rīga, activists joined with like-minded campaigners in Vilnius (e.g. Lithuania Gay League) and Tallinn (e.g. Estonian LGBT Association) to form the regional Baltic Pride movement. In 2009, the first Baltic Pride took place in Rīga. Successive Baltic Prides were held in Vilnius (2010, 2013), Tallinn (2011, 2014), Rīga (2012) and EuroPride (2015).

Out of the three Baltic countries, Lithuania struggles the most in terms of LGBT rights (FRA, 2014). Although homosexuality was decriminalised in 1993 and discrimination is against the law, same-sex civil partnerships and/or marriage are not available and there is no recognition of, or services for, transgender individuals and communities. Attempts to hold a Pride parade in 2007 were blocked when the Vilnius City Council refused to give permission for the public gathering. Violent attacks against Pride parades 
(Blagojević, 2011; Takás \& Borgos, 2011) and the refusal to grant Pride parades access to public spaces (Holzhacker, 2012; O’Dwyer \& Schwartz, 2010) were not uncommon during the 2000s in countries that were previously under Soviet rule.

Lithuania's first Pride took place in 2010 under the banner of Baltic Pride. An initial court decision to prevent the parade on grounds of security was overturned a few days before the event. Despite having been granted the right to peaceful assembly, the participants of Baltic Pride 2010 experienced severe verbal and physical intimidation and violence, which was compounded by poor policing. During the 2013 'March for Equality' circumstances improved slightly when a strong police presence protected the 500 participants against 1000 onlookers, who were mostly homophobic protesters (cf. Lithuania Gay League: National LGBT Rights Organization: http://www.lgl.lt/en/).

Baltic Pride parades in Tallinn appear to have received the least violent public opposition compared with Rìga and Vilnius. A recent European-wide survey (FRA, 2014 ) indicates that $38 \%$ of Estonian respondents reported discrimination based on sexual orientation compared with 48\% Latvians and 61\% Lithuanians. In Estonia, homosexuality and transgender are both recognised in law, and the government legalised the rights of same-sex couples on $1^{\text {st }}$ January 2016 with the introduction of a cohabitation agreement. However, these legislative rights exclude the right to marry, surrogacy and adoption, and as the figures indicate over a third of LGBT people continue to experience discrimination.

This brief, descriptive sketch of Baltic Pride demonstrates the context for EuroPride 2015; it also evidences the failures to protect LGBT human rights. A key point is that Baltic Pride as an annual public event has a short history. Previous Pride parades in Eastern Europe were supported by small numbers of participants (often only 100s) and are largely unsupported by states and state authorities (Kahlina, 2014); most have received violent homophobic opposition. These circumstances are in sharp contrast to the huge, commercialised, mostly peaceful Pride spectacles that take place around the world. For example, in 2015: Sydney Mardi Gras, which was in its 37th year, attracted approximately 400,000 people; São Paulo LGBT Pride Parade, which was in its $19^{\text {th }}$ year 
had a record 5 million participants; and San Francisco Pride, one of the oldest and in its 45th year, attracted over 1 million people.

\section{Methodology}

The analyses that form the second part of this paper are constituents of a larger ongoing qualitative research project that involves participation at Rïga EuroPride (June 2015), Vilnius (June 2016) and Tallinn (July 2017) Baltic Prides. The research project closely aligns with Denzin and Lincoln's advocacy that qualitative research (2005), '... is a situated activity that locates the observer in the world' (3). In this regard, participating at (immersion) Pride events is fundamental to 'data' collection and my research approach reflects a combination of ethnography and autoethnography.

In 2015, I volunteered to work at EuroPride (15 $15^{\text {th }} 2^{\text {nd }}$ June). During my initial contact with organisers, and later with volunteers, I acknowledged my status as UK academic conducting research. ${ }^{x i}$ As a volunteer, researcher and activist I attended a range of Pride-related activities; I spent time 'hanging out' with other volunteers in the spaces and places of EuroPride 2015. Researchers interested in real world issues frequently take an ethnographic and/or autoethnographic approach. They believe that meanings and knowledge-claims are formed and re-formed by people and their communities through a plethora of interactions. Usually, there is homology between researchers' philosophical stance (e.g. interpretivism, constructivism), methods of inquiry (e.g. immersion, observation, analysis of cultural archives and written text, and interviews) and research ethics (e.g. reflexivity, researcher-researched power relations). Some ethnographers and autoethnographers claim they work in partnership and/or collaboration with research participants (e.g. feminist peace (Confortini, 2012); feminist communitarian (Denzin 1997)); most affirm that the research findings they secure are researcher-specific, provide partial 'truths' and cannot be universalised (Davies, 2005). In this way, ethnography and autoethnography reflect aspects of feminist epistemology and methodology as outlined during the late 1980s-early 1990s (cf. Alcoff \& Potter 1993; Harding 1987), specifically Haraway's (1988) notions of situated knowledges, partiality, positioning and accountability. The research that underpins this paper must be understood through this methodological lens, which combines ethnography, autoethnography and tenets of feminist methodology. 
Ethnography and autoethnography as methods of inquiry refer to a gamut of research methods, in this case observation, participant observation, reflexivity, semi-structured interviews, and scrutiny of relevant public materials. Ethnographic and autoethnographic methods elicit findings that are manifest in photographs, field notes including autoethnographic narrative, and interview transcripts. The research findings embedded within the following analyses appear as photographs, field notes that are more akin to autoethnographic narrative, and commentary from the interview participants. To demonstrate the conceptual value of vernacularization to research on human rights, analyses critically explore two main themes: EuroPride 2015 Pride House and EUroPride's Super VIPs

\section{EuroPride 2015 Pride House}

Pride Houses have appeared in conjunction with EuroPride $(2014,2015$ \& 2016) as well as at some mega-sport events. ${ }^{x i i}$ At EuroPride 2014 in Oslo, Pride House (PH) was described as:

[0]ur main arena for politics and debate. ... At Pride House people meet to discuss issues that are important for the lgbtiq community. ... activists and decision makers meet and join each other in a mix of debates, lectures and workshops. Pride House is a space for everyone, young and old, people of any gender expression or identity, whether you are lesbian, gay, bisexual, trans, intersex, queer, a friend, family or support lgbtiq people - Pride House is your arena! (http://www.europride2014.com/hjem/pride-house-2014/)

A similar, but contextually very different missive went out to observers of EuroPride 2015. The details included the fact that PH was open daily from 18th May 2015 - a month prior to Pride. At the opening, a rainbow flag was elevated.xiii This was significant because as stated: 'The rainbow flag that will be raised in their yard [Kan,epes Kultūras Centrs] will be the first time in Latvia's history when a rainbow flag has been openly flown in a public arena' (http://www.europride2015.eu/pride-house-is-open/). For the week of EuroPride 2015, PH was defined as:

... the central gathering location for the participants of EuroPride 2015... the place for cultural and social contacts, as well as one of the main venues of events. Everyday Pride House will host several workshops, discussions, part of the film 
festival "The Black Carnation", and the exhibition "LGBTI in Latvia from the beginning of the 20th century". (ibid)

A cursory comparison of the rhetorics of PH 2014 and PH 2015 highlights an emphasis on politics, activism and policy debates in the former, and social interactions and cultural associations in the latter. During the 3-paragraph publicity for PH 2015, reference to LGBTI appears once when Mozaìka acknowledge their gratitude for support from Kan,epes Kultūras Centrs: 'We are very happy that such a popular, cultural place in Riga are ready to openly stand up for the rights of the LGBTI community'. This PH rhetoric signals the local conditions, and vernacularized strategies of the Pride movement evident in Rīga. In this instance, for the Latvian organisers discourses of culture and gratitude are favoured over the political and oppositional, which are more evident in the description for EuroPride 2014.

I visited PH every day for the week-long EuroPride 2015. On all occasions, two police vehicles were parked outside the building (Photograph 1). Surprised by the surveillance, I mentioned it to the person working behind the bar. He retorted, pithily; 'it's east Europe'. It took time to adjust my cultural compass, which provides some insight into my initial presumptions surrounding the ease of LGBT activism in Rīga.

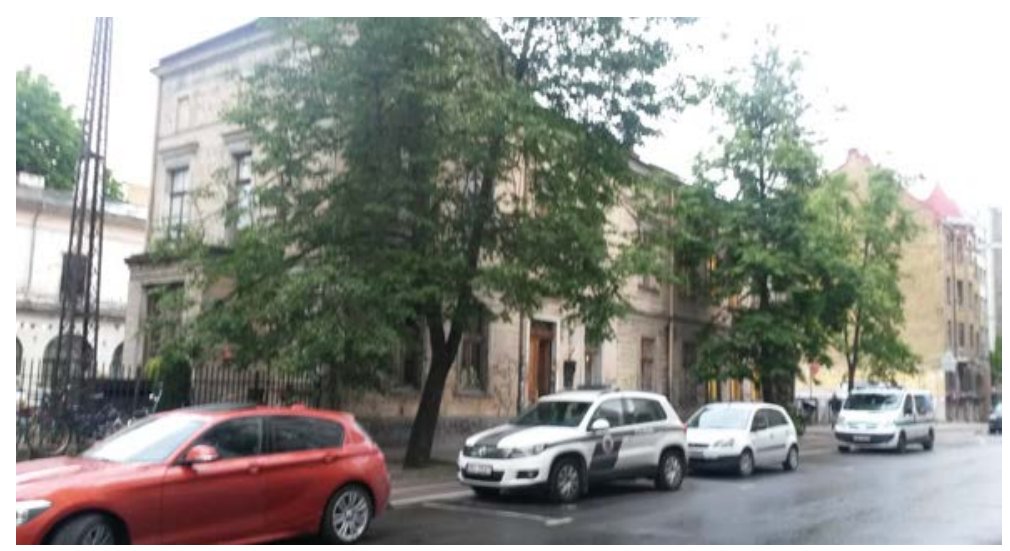

Entering PH involved climbing a few steps and pushing open a tall wooden door. The door was always closed and there were few external signs that this was PH. Once in the building a small rainbow flag was evident behind the bar. To spot the EuroPride information desk, which was draped with a large rainbow flag and other Pride paraphernalia, involved walking around a corner into a small annex off the main room. 
On the ground floor, next to the bar area was a room that doubled as a gallery and workshop space, and on the second floor a 30-seater cinema and large open space, which was used for the LGBTI in Latvia Exhibition and workshops. Doors from the bar area opened on to an outdoor space with seating, plant pots, sculptures and murals.

During my first few days, I interpreted the various spatialities of PH as heterosexual. The regular attendees appeared alternative in their stylexiv and opposite-sex friends/couples were easy with their displays of affection. Occasionally this arrangement was dislocated when groups and/or individuals arrived seeking information about EuroPride. These sexualised spatialities did shift towards the end of the week, as PH became visually LGBT through embodiments of same-sex affection and adornment.xv $^{\mathrm{x}}$

PH is where I met EuroPride organisers and many of the team of 34 volunteers. It is where I observed activities and interactions, including for example, a number of TV and radio crews conducting interviews with organisers and volunteers. It is where I heard contemporary political and legal stories about, for instance: Edgar Rinkēvičs (Latvian foreign minister) outing himself publicly via \#ProudToBeGay (November 2014); the Parliamentary meeting on the Thursday of EuroPride to secure a 'morality bill' (Education Law advocating constitutional definition of marriage as a union between a man and a woman); the on-going public petition to collect and present 10,000 signatures in favour of same-sex marriage; and the activities of Pride opposition group Antiglobalisti who had filed a request for a public gathering in the same park on the same day as EuroPride (the court denied their request on the Thursday of EuroPride week).

PH is where I met the Latvian women I interviewed. Emīlija (aged 25), who identified as heterosexual, worked for Mozaīka and was in charge. Elīza (aged 26), a EuroPride volunteer as well as a volunteer for Mozaīka for the last 3 years. Marika (aged 21) a EuroPride volunteer; this was her first contact with Pride and Mozaīka. Dāniela (aged 30) a EuroPride volunteer who identified as heterosexual, and was in charge of organising the group of 35 volunteers for the weeklong events and activities. All four women were positive, enthusiastic and excited about EuroPride. Their enduring 
energies were palpable. Like many of the volunteers they slept little during EuroPride: 'The last month ... we were working like crazy, leaving the office at midnight almost everyday, crazy. It was the event we had to do. It wasn't about being home early' (Emīlija). In terms of describing themselves as LGBT activists, their answers were not straightforward. Elīza's, who identified as lesbian, response demonstrates the uncertainty:

El: I don't know. It doesn't seem like real activism, but it's part of it. ... I do it because it is important for me. To help a bit, to change things, to make it easier for everybody else.

Marika, who described her sexuality as 'open', talked further about her involvement in and understanding of activism:

A few years back, I participated in Race for the Baltic... they have a bike ride along the Baltic Sea, I participated in collecting signatures so they could be passed on to governments to save the Baltic Sea....

My mum ... she got the newsletter, it was all about EuroPride and also that Mozaika were looking for volunteers. ... I kept reading the programme and actually my mum was like the one who said 'can you volunteer?' I looked it up and 'oh, yes, actually, I can'. 'Actually I should'.

The women interviewed talked about wanting an equal Latvian society, wanting equality for Latvian LGBT peoples, and wanting to help make this happen through EuroPride 2105: 'In this country we really do see the problem with LGBT issues. I feel like I have to help because it's just so bad' (Dāniela). During the interviews, universal human rights-in the official UN and EU legislative formulas identified above-were not talked about. This lack of reference to legal discourse was also evident during my interactions at PH. Many of the people I had informal conversations with were involved with LGBT issues for the first time, or had been involved for the past two to three years $^{\text {xvi }}$ because they wanted to improve LGBT equality. What was striking was the volunteers were aged between 16 and 30 years old and about half of the group identified as heterosexual. In their research on transnational LGBT activism in Poland, Binnie and Klesse (2012) observed a similar finding that both activists and their organisations were younger compared to countries such as Holland. 
It was apparent that PH was 'the central gathering location for the participants of EuroPride 2015'. Despite an apparent lack of human rights rhetorics, there was evidence of positive discourses of LGBT equality and a strong shared commitment to the finale Pride parade. Perhaps we can conclude that universal human rights instruments were largely meaningless in this local setting. However, Pride was articulated in the form of a strong commitment to equality, diversity and a just society. PH provided a focal point for people, ideas and activities that helped constitute the Pride Movement. In this way, the broader practices of Pride were favoured over overt legal and political discourses of universal human rights (e.g. UNHR, EU Fundamental Rights).

\section{EUroPride's Super VIPs}

The most overt appropriation of universal human rights at EuroPride 2015 was at the one-day conference: Freedom of Speech and Assembly: A World Perspective in a Narrative. In terms used by Merry (2006, 2009), the vernacularization of freedom of assembly ${ }^{x v i i}$ was 'thinly adapted'. The conference was held centrally at the global-chain Radisson Blu 4-star hotel. All speakers stressed the importance of the universal human right—freedom of assembly—to processes of democracy. The speakers were:

-Andrea Wiktorin: Ambassador of Germany to Latvia -Baiba Braže: Ambassador Director General, Director of Security Policy and International Organisations, Ministry of Foreign Affairs of the Republic of Latvia -Randy Berry: US State Department Special Envoy for the Human Rights of LGBTI -Stuart Milk: Co-founder of the Harvey Milk Foundation (USA)

-Dennis Van Der Veur: Head of Sector Coop with EU institutions \& EU member States, EU Agency for Fundamental Rights -Colm O'Gorman: Executive Director, Amnesty International, Ireland -Shawn Gaylord: Advocacy Counsel Human Rights First (USA) Final Speaker: Steiner Egil Hagen: Norwegian Ambassador to Latvia

The majority of these advocates also formed the lead group of the Pride procession; volunteers and organisers referred to them as Super VIPs. The women I interviewed viewed the presence of diplomats from embassies as well as high-ranking personnel from non-government organisations (NGOs) as positive, both financially and morally:

We got a lot of money from embassies. The embassies that support human rights to LGBT. The US embassy was a huge, huge support, they were the main supporter. The Netherlands, the Belgians I think, the German embassy, well the German Government actually, they financed the Freedom Conference. (Emìlija) 
... they come from Netherlands or USA, they are really sure of themselves and they know what can be achieved. It's not achieved here ... they know what they are doing so they have all this good experience, which I think really helps. (Marika)

From my observations, a range of people attended the conference, for example, during a coffee break I spoke with a woman from Bratislava; a chemistry student who volunteered for Amnesty International. At lunchtime, I sat with a man from USA who self-identified as Christian and gay and a German diplomat who self-identified as heterosexual (he brought his two young children and partner to the Pride parade).

As Holzhacker (2012) argues, Pride and related public manifestations are significant in bolstering the 'social capital' (24) of the LGBT movement. Diplomats, members of NGOs and people from outside of Latvia attended the conference and the event received positive local media coverage. Compared with Rīga Pride events of 2005-2008, the contrasts are discernible, namely international and national legitimacy, which can function to change social attitudes and assist local actors and activists.

At the same time as remaining respectful of the women interviewees' views, and mindful of the kudos garnered by the high-profile conference, it is important to offer a critique of how and why universal human rights travel to destinations such as Rīga, and imagined destinations such as Moscow (Photograph 2). As one way to highlight the influence of the west/global north, I borrow from Woodcock (2011) the capitalisation 'EU'. She uses it to pronounce the strong influence of the European Union. Her stylisation serves as a trope, which enables a view of West to East transnational power relations. It alludes to how eastern European countries, for example Latvia (and an envisaged Moscow), become 'an object of Western pedagogy' (Kulpa, 2011: 49).

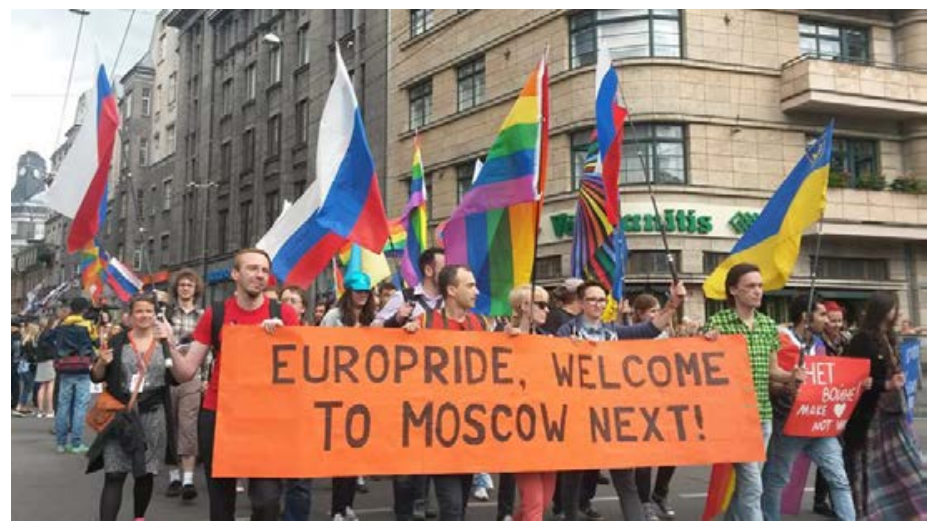


Woodcock (2011) is not alone in her critique and recent collections concerning sexualities and genders in CEE (e.g., Ayoub \& Paternotte, 2014; Kulpa \& Mizielińska, 2011), question the assumed 'geotemporal dimensions of sexual politics', the monolithic of 'Western activism' (Mizielińska \& Kulpa, 2011: 13), and the 'logics of 'Western' models of cultural and political agency' (Blagojeveić, 2011: 31). For instance, Mizielińska (2011) claims that: 'Polish LGBT activism cannot be categorized simply as 'identitarian' or 'queer' because it exists in a different geotemporality from the 'West" (85).

Moreover, Binnie and Klesse (2011) argue, in the context of their research, that 'Western European activists acting 'in support' of struggles in Central and Eastern Europe ... reinforce Western European cultural hegemony in sexual politics' (107). Or, as Woodcock (2011) explicates, the process serves the west, because it: 'benevolently bestow(s) recognition on its 'other"(65). The trope EUroPride provides a critique of the idea of 'the singular trajectory of European development' (Woodcock, 2011: 65). It also represents criticism of dominant EU-related notions of 'liberation', 'progress', 'democratisation', and 'modernisation' (Binnie \& Klesse, 2011: 107). The point is that the framing of sexual politics through these western and west European discourses '[a]llows the west to place itself 'above'/'before', as the mentoring force ...' (Mizielińska and Kulpa, 2011: 17) thus serving to ensure a future assumed as an 'advanced political culture around gender and sexual equality' (Binnie \& Klesse, 2011: 107).

EUroPride's Super VIPs who promoted rhetorics of universal human rights, and sentiments of intervention such as those encapsulated in the US Embassy-endorsed slogan: "Changing History is HOT" (Photograph 3) represent both promise and problematic. The promise is that EUroPride 2015 parade is an entitlement under international human rights law (freedom of assembly), which serves to transform the lives of LGBT. As Woodcock (2011) posits, CEE societies are often perceived by the west as 'in a stagnant moment of time before capitalism and after socialism' and 'lagging behind' (65). The problematic is that this right to assembly is presumed as the only transformative driver of LGBT rights in Latvia, and similarly-imagined CEE countries. 


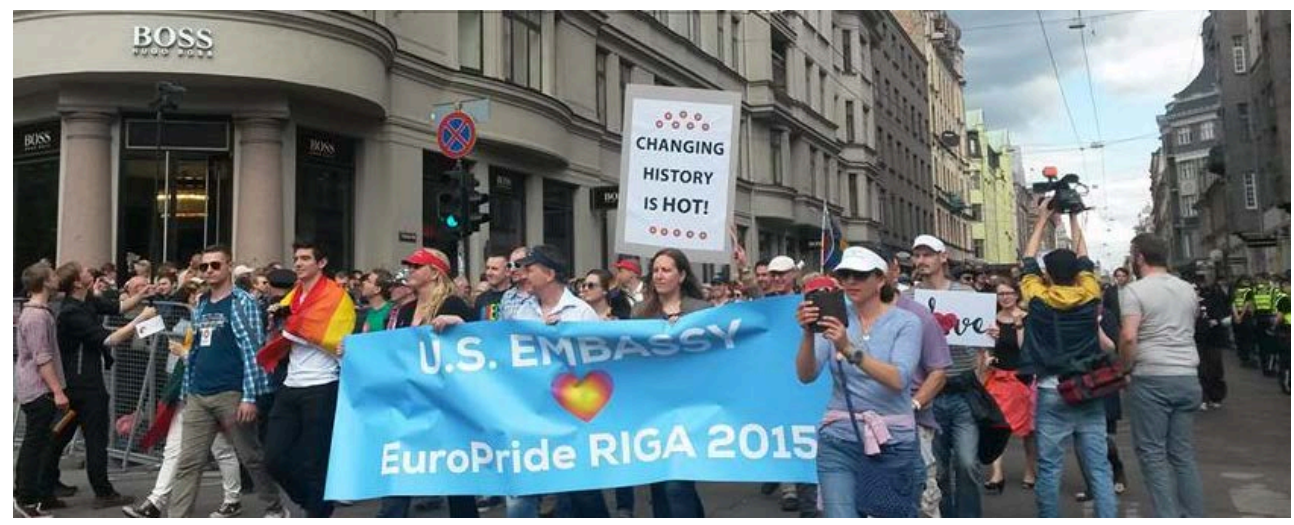

Since joining the EU, many CEE member states have complied with requirements to decriminalise homosexuality, specifically same-sex sexual activity between consenting adults (Takács \& Borgos, 2011) thus abiding by the universal human right of freedom of expression. Albeit LGBT rights as confined to the private sphere of the home. However, existing EU interventions such as this, and the conference call for freedom of assembly, have led some opposition groups to adopt the term Eurosodomites (Kulpa \& Mizielińska, 2011). This is because they see homosexuality as produced through western legislative frames.

The main opposition at EuroPride 2015 was a group called Antiglobalisti. They publicly protested at Vērmanes Dārzs Park during the Pride parade. Their protest slogans included: "we are against homosexual propaganda" and "we are for traditional family", "No - to promotion of mental deviations! NO - PRIDE!" and "Sodom Go Home". The police arrested a small number of opposition. For example, I saw them arrest a man who set fire to a Pride rainbow flag at the entrance to the Park, and according to Dāniela, "the main orgainser of the protest was arrested, before the Pride because he tried to protest in the wrong place".

In the past, Latvian state authorities have not been so vigilant. O'Dwyer and Schwartz (2010) discuss '[a]ggressive antigay rhetoric by political elites' (224). They conclude that 'state discrimination against sexual minorities ... results from a particular interaction of religion, national identity and party system' (222). Focusing on the latter-party system — they identify key Governmental roles vis-à-vis national human rights policy, which were occupied by homophobic politicians. For example, in 2006: 
Jānis Šmits, the party's most aggressive antigay voice, was made chairman of parliament's human rights committee, and LPP [Latvia's First Party] member Oskars Kastēns was appointed Special Assignments Minister for Social Integration. (Ibid: 230)

As Holzhacker (2012) points out, social change requires political party support. It is interesting to note that of the eight speakers (Super VIPs), only one represented Latvia (Braže: Director of Security Policy and International Organisations). When I asked Emìlija if the Latvian Government supported EuroPride, she replied: "They were helping in a way that they were not doing any harm for us". She went on to talk about the mayor of Rīga and his lack of public conviction to EuroPride: "he cannot support us openly because his voters are mostly super homophobic and he's also connected to, like the three Russian parties. So he's a really tricky politician." Although I am not able to verify these comments, they do offer something of the local political context. Explicit discussion of this local political power base was absent from the conference, and the Super VIPs appeared to ignore it as well as the often-violent homophobic responses to previous Pride events.

The large prestigious conference funded by German authorities, in the plush surrounds of a globally recognised hotel chain, the day before the EuroPride parade, promoted the universal human right of freedom of assembly. Universal human rights rhetoric traveled with Super VIPs from sites of production such as the USA (e.g. US Special Envoy for the Human Rights of LGBTI) to the locale Latvia. This universal human right was thinly adapted to the socio-cultural and political context, which included often-vile opposition from groups such as Antiglobalisti and strategic apathy from political parties. At this juncture, a return to Cheng's question springs to mind: 'for whose good?' was the universal human right—freedom of assembly—transposed? The answers might reside with existing critical discussions of SOGI that interrogate transnational relations specific to the emergence and order of an enlarged Europe, and the socio-cultural and political currents of Europeanisation (cf. Binnie \& Klesse, 2011; Kalina, 2014; Mizielińska \& Kulpa, 2011; Woodcock, 2011). 


\section{Concluding comments}

EuroPride 2015 occurred in a particular, local socio-cultural and political context. Despite universal human rights discourses applicable to LGBT and the global Pride movement as well as pan-European and Baltic Pride movements, it is important to focus on this locale. In doing so, we must remain mindful of the prevailing social constructions of sexualities and genders (Murray, 2006; O’Dwyer \& Schwartz, 2010). In particular, and in relation to Latvia, this means attention to the moral histories of nationalism, religiosity, theology and party politics. All of which shape vernacularization of human rights.

In this paper, I offer a perspective of days spent at PH as a way to document levels of Pride activisms and LGBT rights claiming in situ. This perspective aids an appreciation of the socio-cultural conditions of daily existence and the quotidian of LGBT activism. It introduces the prevalence of young people and non-LGBT individuals to struggles for LGBT rights to equality. It is not uncommon for youth to play active roles in shaping social currents during times of societal transition (Binnie \& Klesse 2012; Ramet, 1991).

The people, activities and interactions at PH were not underpinned by an explicit deployment of, or adherence to universal human rights legislation. Official universal human rights, including a 'Ghostly' ephemeral presence, were absent. Instead, vernacularization of rights involved small-scale social interactions and broader cultural associations attached to contemporary political and legal stories, and LGBT forums, art and film.

Universal human rights were blatant at the Freedom of Speech and Assembly conference. And yet, it can be argued that human rights advocates presented a bland option given available official human rights legal frameworks. In the section concerning SOGI and human rights, I highlight an emerging focus by the UN and EU on violence, especially overt public homophobic and transphobic attitudes and behaviours, and emerging anti-discrimination law. This legislative focus did not figure at the conference. Official public dialogue concerning the often-vile homophobic opposition to Pride, and the strategic apathy from political parties and state authorities were noticeably missing from the conference agenda. 
In terms of vernacularization, the universal human right to assembly was thinly adapted. The conference and Pride parade functioned as showcases for Super VIPs to transpose universality, albeit largely EUropeanised universality. Scholars of sexual politics (e.g. Kulpa \& Mizielińska, 2011) have offered convincing critiques of west to east transnational flows, which migrate western-centric dominant versions of modernisation, liberation, progress and democratisation vis-à-vis gender and sexual minorities. These criticisms are applicable to an analysis of EuroPride's Super VIPs.

Conceptually, vernacularization offers a socio-culturally sensitive approach to explore how and why universal human rights inscribed within legislative frameworks develop, travel, and are known, adopted and ignored. Such an approach enabled a particular examination of LGBT human rights at EuroPride 2015.

\section{References}

Alcoff, L. and Potter, E. (1993) Feminist Epistemologies. London: Routledge

Ayoub, P.M. and Paternotte, D. (2014)(Eds) LGBT Activism and the Making of Europe: A Rainbow Europe. London: Palgrave

Binnie, J. and Klesse, C. (2012) The Politics of Age, Temporality and Intergenerationality in Transnational Lesbian, Gay, Bisexual, Transgender and Queer Activist Networks, Sociology 47(3): 580-595

Binnie, J. and Klesse, C. (2011) Researching Transnational Activism around LGBTQ Politics in Central and Eastern Europe: Activism Solidarities and Spatial Imaginings, in R. Kulpa and J. Mizielińska (Eds)(2011) De-centring Western Sexualities: Central and Eastern European Perspectives. Farnham: Ashgate, pp. 107-130

Blagojević, J. (2011) Between Walls: Provincialism, Human Rights, Sexualities and Serbian Public Discourses on EU Integration, in R. Kulpa and J. Mizielińska (Eds)(2011) De-centring Western Sexualities: Central and Eastern European Perspectives. Farnham: Ashgate, pp. 27-42

Boyce, P. (2014) Desirable rights: Same-sex sexual subjectivities, socio- economic transformations, global flows and boundaries - in India and beyond, Culture, Health \& Sexuality: An International Journal for Research, Intervention and Care, 16(10): 12011215

Cheng, S. (2011) The Paradox of Vernacularization: Women's Human Rights and the Gendering of Nationhood, Anthropological Quarterly, 84(2): 475-505 
Confortini, C.C. (2012) Intelligent Compassion: Feminist Critical Methodology in the Women's International League for Peace and Freedom. Oxford: OUP

Council of Europe (2011) Combating Discrimination on Grounds of Sexual Orientation or Gender Identity. Strasbourg: Council of Europe Publishing

Council of the European Union (2000) Charter of the Fundamental Rights of the European Union. Nice: The European Parliament, the Council and the Commission

Davies, C. A. (2005) Reflexive Ethnography. London: Routledge

Denzin, N. (1997) Interpretive Ethnography. London: Sage

Denzin, N. and Lincoln, Y. (Eds)(2005) The Handbook of Qualitative Research. London: Sage.

Dzenovska, D. and Arenas, I. (2012) Don't Fence Me In: Barricade Sociality and Political Struggles in Mexico and Latvia, Comparative Studies in Society and History, 54(3): 644678.

FRA - European Union Agency for Fundamental Rights (2015) Human rights of intersex people: challenges ahead. Available online at:

http://fra.europa.eu/en/event/2015/human-rights-intersex-people-challenges-ahead [accessed 7 August, 2015]

FRA - European Union Agency for Fundamental Rights (2014) EU LGBT Survey: European Union Lesbian, Gay, Bisexual and Transgender Survey. Main Results.

Luxemburg: Publications Office of the European Union.

FRA - European Union Agency for Fundamental Rights (2014) Being Tans in the European Union: Comparative Analysis of EU LGBT Survey Data. Luxemburg: Publications Office of the European Union.

Haraway, D. (1988) Situated Knowledges: the Science question in feminism and the Privilege of Partial Perspective, Feminist Studies, 14(3): 575-599

Harding, S. (1987) Feminism and Methodology. Milton Keynes: OUP

Holzhacker, R. (2013). State-sponsored homophobia and the denial of the right of assembly in Central and Eastern Europe: The 'boomerang' and the 'ricochet' between European Organizations and Civil Society to uphold human rights. Law and Policy, 35(12), 1-25.

Holzhacker, R. (2012) National and transnational strategies of LGBT civil society organizations in different political environments: Modes of interaction in Western and Eastern Europe for equality, Comparative European Politics 10(1): 23-47 
Kahlina, K., (2014) Local histories, European LGBT designs: Sexual citizenship, nationalism, and "Europeanisation" in post-Yugoslav Croatia and Serbia, Women's Studies International Forum, dx.doi.org/10.1016/j.wsif.2014.07.006

Kulpa, R. (2011) Nations and Sexualities - 'West' and 'East', in R. Kulpa and J. Mizielińska (Eds)(2011) De-centring Western Sexualities: Central and Eastern European Perspectives. Farnham: Ashgate, pp. 43-62

Kulpa, R. and Mizielińska, J. (2011) De-centring Western sexualities: Central and Eastern European perspectives. Farnham: Ashgate

Lamond, I., and Spracklen, K. (2014) (Eds) Protests as events: Politics, activism and leisure. London: Rowman \& Littlefield International

Levitt, P. and Merry, S. (2009) Vernacularization on the ground: Local uses of global women's rights in Peru, China, India and the United States, Global Networks, 9(4): 441461.

Merry, S. (2006) Transnational Human Rights and Local Activism: Mapping the Middle, American Anthropologist, 108(1): 38-51

Merry, S. (1997) Legal Vernacularization and Transnational Culture: the Ka Ho'okolokolonui Kanaka Maoli, Hawai'i 1993, in R. Wilson (Ed) Human Rights, Culture and Context: Anthropological Perspectives. London: Pluto Press, pp. 28-49.

Mizielińska, J. (2011) Travelling Ideas, travelling Times: On the Temporalities of LGBT and Queer Politics in Poland and the 'West', in R. Kulpa and J. Mizielińska (Eds)(2011) De-centring Western Sexualities: Central and Eastern European Perspectives. Farnham: Ashgate, pp. 85-106

Mizielińska, J. and Kulpa, R. (2011) 'Contemporary Peripheries: Queer Studies, Circulation of Knowledge and East/West Divide, in R. Kulpa and J. Mizielińska (Eds)(2011) De-centring Western Sexualities: Central and Eastern European Perspectives. Farnham: Ashgate, pp. 11-26

Murray, D. (2006) Who's Right? Human Rights, Sexual Rights and Social Change in Barbados, Culture, Health \& Sexuality, 8(3): 267-281

Nicholson, L. (1990)(Ed) Feminism/Postmodernism. London: Routledge

O’Dwyer, C. and Schwartz, K.Z.S. (2010) Minority rights after EU enlargement: A comparison of antigay politics in Poland and Latvia, Comparative European Politics 8(2): 220-243

Ramet, S. (1991) Social Currents in Eastern Europe. London: Duke University Press

Reuters (2015) Gay Pride March Attacked in Kiev, The World Post. Available online at: http://www.huffingtonpost.com/2015/06/06/gay-pride-kiev n 7525194.html [accessed 3 June, 2015] 
Swiebel, J. (2009) Lesbian, Gay, Bisexual and Transgender Human rights: The Search for an International Strategy, Contemporary Politics, 15(1): 19-35

Takács, J. \& Borgos, A. (2011) Voicing Women in Eastern Europe-An Introduction, Journal of Lesbian Studies, 15(3): 265-270

Takhar, S. (2015) Sustainability, human rights, and sexuality: Making the right connections, Local Economy, 30(3): 256-264

United Nations (2014) 27/... Human rights, sexual orientation and gender identity A/HRC/27/L.27/Rev.1. Vienna: UN

United Nations (2011) 17/19 Human rights, sexual orientation and gender identity A/HRC/RES/17/19. Vienna: UN

United Nations (2011) Discriminatory laws and practices and acts of violence against individuals based on their sexual orientation and gender identity - A/HRC/19/41. Vienna: UN

United Nations Human Rights Office of the High Commission (2012) Born Free and Equal: Sexual Orientation and Gender Identity in International Human Rights Law. New York: UN

Woodcock, S. (2011) A Short History of the Queer time of 'Post-Socialist' Romania, or Are We There Yet? Let's Ask Madonna, in R. Kulpa and J. Mizielińska (Eds)(2011) Decentring Western Sexualities: Central and Eastern European Perspectives. Farnham: Ashgate, pp. 63-83

\footnotetext{
i The International Commission of Jurists (ICJ) raised concerns in 2003 and began the project of documenting UN references to violations experienced by LGBT individuals. It issued its first UN compilation in 2005.

ii Entitled: Discriminatory laws and practices and acts of violence against individuals based on their sexual orientation and gender identity

iii Established in 1978 and gained access to EU in the 1990s, specifically the European Parliament and European Commission.

iv Any discrimination based on any ground such as sex, race, colour, ethnic or social origin, genetic features, language, religion or belief, political or any other opinion, membership of a national minority, property, birth, disability, age or sexual orientation shall be prohibited.

v Council of Europe (2011) Combating Discrimination on Grounds of Sexual Orientation or Gender Identity.

vi She acknowledges that these agents have cultural capital; they are often from the middle-classes.

vii Murray borrows this term from Chambers (2003) and his concept of 'Ghostly Rights'. I use it here to refer to Pat's sometimes-wafted sheets of paper.

viii The 2014 release of the film Pride, which is about the 1984 London Pride parade, provides a popular cultural representation of the ethos that Pride intends to evoke.

ix For an account of the religious and political opposition to Rīga Prides 2005-2009 see: Homo@lv available online at: https://vimeo.com/38177969

x In recent years Mozaīka has delivered formal anti-homophobia training/workshops to police personal

xi Related to ethical considerations, a University of Sussex Ethical Review was completed and authorised, it highlighted my adherence to fundamental ethical matters such as consent, anonymity (use of psydonyms) \& confidentiality.
} 
xii Pride House International at Vancouver winter Olympics 2010, London summer Olympics 2012 and Glasgow Commonwealth Games 2014.

xiii The flag was at the top of internet/phone aerial. It was a small flag, but it did remain in place.

xiv For me, this means 'hippy', 'new age', 'arty'. Other examples include the food that was served at PH was vegetarian only and one regular brought his two children, they all arrived on skateboards. The two children played inside and outside PH and several other adults looked after/engaged with them.

xv For me, this means, for example, being introduced to a same-sex partner as 'my husband', observing female masculinity and male femininity (including 'camp'), and seeing T-shirts that declared transgender. xvi Note: EuroPride was awarded in 2012

xvii Article 20.1 Everyone has the right to freedom of peaceful assembly and association. 